\title{
Медоносні рослини дендрофлори Чернелицького лісництва: аналіз та охорона (Прут-Дністровське межиріччя)
}

У статті досліджено медоносні рослини в дендрофлорі лісових фітоценозів Чернелицького лісництва (ПрутДністровське межиріччя). Обстежено лісові деревостани та вирубки лісництва, складено конспект дендрофлори, виявлено медоносні деревні рослини, проведено їх аналіз, названо найбільш цінні медоноси, визначено їх нектаропродуктивність і вказано народногосподарське значення. Розроблено деякі заходи щодо збереження та охорони медоносних рослин у лісництві.

Ключові слова: лісові фітоценози, дендрофлора, види, медоносні рослини, природні ресурси, рослинність.

Постановка наукової проблеми та її значення. У сучасних умовах усе зростаючого техногенного й антропогенного впливу на довкілля простежено стійку тенденцію до зменшення чисельності багатьох видів рослин, у тому числі й цінних народногосподарських, харчових, лікарських, медоносних тощо. Тому охорона біорізноманіття, раціональне використання та відтворення генофонду диких предків цінних сільськогосподарських рослин - одна з актуальних проблем сьогодення. Серед багатьох видів, що зростають у лісових екосистемах, великий інтерес викликають медоносні рослини, які $\epsilon$ не лише джерелом харчових і лікарських продуктів та відзначаються високими смаковими й поживними якостями, але й мають цінну деревину зі специфічною декоративною текстурою. Саме тому в сучасних умовах набуває актуальності всебічне вивчення дикорослих медоносних рослин і розробка наукових основ їх охорони, відтворення й раціонального використання.

Своєрідна та багата рослинність Прут-Дністровського межиріччя здавна привертала увагу ботаніків, систематиків, геоботаніків, палеонтологів тощо. Вивчення природи й рослинності регіону має досить давню історію. Деякі відомості про флору цієї області знаходимо в стародавніх джерелах записах окремих мандрівників (Е. Лесота,1594; В. Боплан,1660). Надалі одними 3 перших дослідників природи цього регіону вже в XIX ст. були природознавці В. Бестер й А. Анджейовський, які вивчали флору краю, провели систематичний опис і зібрали великий гербарій рослин. У радянський період вивченню рослинного покриву регіону багато уваги приділяли ботаніки Львівського державного університету ім. І. Франка, Інституту ботаніки АН України ім. В. Холодного, Українського науково-дослідного інституту гірського лісівництва та ін. Проте наукових праць із вивчення фітоценозів саме району Чернелиці й аналізу в них медоносних рослин нами не виявлено.

Мета статті - вивчити медоносні рослини дендрофлори фітоценозів Чернелицького лісництва та розробити заходи щодо їх ефективного відтворення. Завдання дослідження включали визначення видового складу дендрофлори лісових фітоценозів лісництва; виявлення в ньому медоносних рослин, систематичний аналіз дендрофлори й медоносів, а також життєвих форм деревних рослин, визначення нектаропродуктивності найважливіших медоносів, їх значення та заходів охорони й відтворення медоносів.

Об'єкт дослідження - лісові фітоценози лісництва; предмет - медоносні рослини дендрофлори лісництва.

Місцезнаходження об'єкта дослідження. Чернелицьке лісництво загальною площею 5414 га, розміщене вздовж правобережжя ріки Дністер на висотах над рівнем моря близько 100-300 (350) м на території Городенківського району Івано-Франківської області.

За фізико-географічним районуванням - це район Придністровського Покуття, що розміщений у межах Прут-Дністровського межиріччя й належить до природної зони лісостепу [5]. За геоботанічним районуванням Г. Білика, $€$ Брадіса, М. Голубця та ін. досліджуваний район належить до ІваноФранківсько-Коломийського району грабово-дубових і дубових лісів [2]. За флористичним районуванням Т. Андрієнко, О. Блюма та С. Вассера з урахуванням робіт Б. В. Заверухи територія лісництва лежить у межах Придністровського району [3; 6, с. 19-20 ]. Тобто пануючими в лісових масивах Чернелицького лісництва є грабово-дубові фітоценози (Carpineto-Querceta) $[2,3,10]$.

Методика. Дослідження дендрофлори медоносних рослин Чернелицького лісництва проводили протягом 2012-2015 рр. Для збору відомчих матеріалів використовували таксаційні описи лісових

(C) Гайдукевич М., 2016 
насаджень лісництва, план лісонасаджень тощо. Польові дослідження здійснювали в лісових фітоценозах лісництва. Обстеженнями охоплено природні ділянки лісових насаджень та вирубок.

При польовому вивченні дендрофлори застосовували маршрутний тип експедиційного дослідження за допомогою закладки тимчасових профільних ліній, максимально приурочених до квартальних просік. Уздовж цих ліній складався список деревних видів, визначалася їхня життєва форма й указувалися медоносні рослини. Рослини установлювалися за Визначником рослин України [4], систематичні таксони приймалися за А. Л. Тахтаджаном [9], життєві форми рослин - за I. Г. Серебряковим [7]. Збір гербарного матеріалу та сушку рослин проводили за загальноприйнятими методиками.

Нектаропродуктивність медоносних рослин визначали за методикою А. С. Швецова та Е. Х. Лук'яненко [11].

Виклад основного матеріалу й обгрунтування отриманих результатів дослідження. Видовий склад дендрофлори пануючих у лісництві грабово-дубових фітоценозів досить багатий. Перший ярус утворений Quercus robur L., Fraxcinus excelsior L., Tilia corbata Mill., Betula pendula Roth.. Дещо відстають у рості, утворюючи другий ярус, Carpinus betulus L., Acer campestre L., Cerasus avium (L.) Moench. Наступний ярус дубово-грабового деревостану - чагарники. Це - Corylus avellana L., Salix caprea L., Euonymus verrucosa Scop., Prunus spinosa L., Crataegus monogyha Jack., Frangula alnus Mill., Sambucus racemosa L., Padus racemosa L., Viburnum opulus L. та ін.

У фітоценозах Чернелицького лісництва виявлено 85 видів деревних рослин, що належать до 26 родин і 53 родів. Найчисельнішими у видовому відношенні є родина Rosaceae (Sorbus aucuparia L., $S$. aria $L$., Rosa canina $L$, $R$.. rugosa $L$, ін.). - 13 видів і форм (17,6 \% дендрофлори), які належать до дев'яти родів (17,6 \%), Pinaceae (Pinus sylvestris L., Abies alba Hill., Picea abies Karst.,iн.) - восьми видів (9,2 \% дендрофлори), що належать до трьох родів (5,9 \%), Cupressaceae (Juniperus communis L., J. sabina L., Thuja occidentalis L., ін.) - п’ять видів і форм (6,2 \% дендрофлори), які належать до чотирьох родів (7,7 \%), Caprifoliaceae (Sambucus nigra L., S. racemosa L., Lonicera xylosteum L, iн) - п'ять видів (6,2 \% дендрофлори), які належать до трьох родів (5,9\%), Fagaceae (Fagus sylvatica L., Querces robur L., Q. borealis Michx., ін.) - чотири види (4,8 \% дендрофлори), Betulaceae (Betula verrucosa Ehrh., B. pubescens Ehrh., Alnus glutinosa (L.) Caerth., ін.) - чотири види (4,8 \% дендрофлори), Aceraceae (Acer platanoides L., A..pseuloplatanus L., A.campestre L., ін.) - чотири види (4,8\% дендрофлори) Решта родин представлені 1-3 видами рослин, що в сумі складають близько 46,4 \% дендрофлори лісництва.

За життєвими формами рослини розподілилися таким чином: дерев - 54 \% (46 видів), кущів 44 \% (37 видів), кущиків - 1 \% (один вид), ліан - 1 \% (один вид). Найчисельнішими за вмістом дерев є родини Pinaceae - вісім видів (Pinus sylvestris L., Abies alba Hill., Picea abies Karst., ін.), Rosaceae п’ять видів (Malus sylvestris Mill.,Cerasus avium (L.) Moench, Pyrus.communis L.., ін.), Salicaceae п'ять видів (Salix alba L., Populus nigra L., P. tremula L., ін.), Fagaceae - чотири види ((Fagus sylvatica L.,Querces robur L.,Q.borealis Michx., ін.), Betulaceae - чотири види (Betula verrucosa Ehrh., B. pubescens Ehrh., Alnus glutinosa (L.) Caerth., ін.), Aceraceae (Acer platanoides L., A. pseuloplatanus L., A. campestre L., ін.) - чотири види. Чагарники найбільше представлені родиною Rosaceae - вісім видів (Rubus idaeus L., Crataegus oxyacantha L., Rosa canina L., R. rugosa L., ін. Ліан - лише один вид із родини Araliaceae (Hedera helix .).

У дендрофлорі фітоценозів лісництва 46 видів (54 \%) відзначено як медоносні рослини. Систематичний аналіз медоносів відображено в табл. 1.

Таблиия 1

Систематичний аналіз медоносних рослин

\begin{tabular}{|c|c|c|c|c|c|}
\hline \multirow{2}{*}{$\begin{array}{c}\text { № } \\
\text { 3/II }\end{array}$} & \multirow[t]{2}{*}{ Родина } & \multicolumn{2}{|c|}{ Кількість родів } & \multicolumn{2}{|c|}{ Кількість видів } \\
\hline & & um. & $\%$ & um. & $\%$ \\
\hline 1 & 2 & 3 & 4 & 5 & 6 \\
\hline 1 & Rosaceae & 9 & 29 & 13 & 28 \\
\hline 2 & Caprifoliaceae & 3 & 10 & 5 & 11 \\
\hline 3 & Salicaceae & 1 & 3 & 4 & 7 \\
\hline 4 & Aceraceae & 1 & 3 & 4 & 7 \\
\hline
\end{tabular}




\begin{tabular}{|c|c|c|c|c|c|}
\hline \multicolumn{6}{|c|}{ Закінчення таблиці } \\
\hline 1 & 2 & 3 & 4 & 5 & 6 \\
\hline 5 & Cornaceae & 2 & 7 & 3 & 7 \\
\hline 6 & Fabaceae & 2 & 7 & 2 & 5 \\
\hline 7 & Grossulariaceae & 2 & 7 & 2 & 5 \\
\hline 8 & Rhamnaceae & 2 & 7 & 2 & 5 \\
\hline 9 & Oleaceae & 2 & 6 & 2 & 5 \\
\hline 10 & Tiliaceae & 1 & 3 & 2 & 5 \\
\hline 11 & Viburnaceae & 1 & 3 & 2 & 4 \\
\hline 12 & Berberidaceae & 1 & 3 & 1 & 3 \\
\hline 13 & Thymelaeaceae & 1 & 3 & 1 & 2 \\
\hline 14 & Cesalpiniaceae & 1 & 3 & 1 & 2 \\
\hline 15 & Celastraceae & 1 & 3 & 1 & 2 \\
\hline 16 & Elaeagnaceae & 1 & 3 & 1 & 2 \\
\hline & Усього, & 31 & 100 & 46 & 100 \\
\hline
\end{tabular}

Як бачимо, медоносні рослини належать до 16 родин та 31 роду. Найчисельнішою родиною за вмістом медоносних рослин є родина Rosaceae (Malus sylvestris Mill., Cerasus avium (L.) Moench, Rubus idaeus L. й ін.) - дев'ять родів (29\%), 13 видів (28\%), 13 видів (12 \% дендрофлори). Друге місце за кількістю медоносів займає родина Caprifoliaceae (Sambucus nigra L., S. racemosa L., Lonicera xylosteum $L$. . ін.), яка нараховує три роди (10\%) та п’ять видів (11\%) медоносних рослин. По чотири види медоносних рослин ми виявили в родинах Salicaceae (Salix alba L., S. caprea L, S. fragilis L., ін.) - 7 \% дендрофлори та Aceraceae (Acer platanoides L., A. pseuloplatanus L., A.campestre L. й ін.) 7 \% дендрофлори. Проте серед найцінніших у медоносному значенні потрібно назвати родини Tiliaceae (Tilia corbata Mill., T. platyphyllos Scop.), Fabaceae (Robinia pscudoacacia L.), Rosaceae (Rubus idaeus L.) i Salicaceae (Salix alba L., S. caprea L, S. fragilis L.).

Аналіз медоносів за життєвими формами відображено в табл. 2.

Таблиия 2

Життєві форми медоносних рослин лісництва

\begin{tabular}{|c|c|c|c|c|c|}
\hline № 3/II & Родина & Дерева & Кущі & Кущики & Усього \\
\hline 1 & Rosaceae & 7 & 6 & & 13 \\
\hline 2 & Caprifoliaceae & & 5 & & 5 \\
\hline 3 & Aceraceae & 4 & & & 4 \\
\hline 4 & Salicaceae & 2 & 2 & & 4 \\
\hline 5 & Cornaceae & & 3 & & 3 \\
\hline 6 & Tiliaceae & 2 & & & 2 \\
\hline 7 & Grossulariaceae & & 2 & & 2 \\
\hline 8 & Fabaceae & 1 & 1 & & 2 \\
\hline 9 & Rhamnaceae & & 2 & & 2 \\
\hline 10 & Oleaceae & & 2 & & 2 \\
\hline 11 & Viburnaceae & & 2 & & 2 \\
\hline 12 & Berberidaceae & & 1 & & 1 \\
\hline 13 & Cesalpiniaceae & 1 & & & 1 \\
\hline 14 & Celastraceae & & 1 & & 1 \\
\hline 15 & Elaeagnaceae & & 1 & & 1 \\
\hline \multirow[t]{3}{*}{16} & Thymelaeaceae & & & 1 & 1 \\
\hline & Усього, ит. & 17 & 28 & 1 & 46 \\
\hline & $\%-100$ & 37 & 61 & 2 & 100 \\
\hline
\end{tabular}

За життєвими формами медоносні рослини розподілилися таким чином: дерев - 37 \% (17 видів), кущів - 61\% (28 видів), кущиків - $2 \%$ (один вид). Найчисельнішою родиною за вмістом медоносних дерев та кущів є родина Rosaceae (Malus sylvestris Mill., Cerasus avium (L.) Moench, Rubus idaeus L., ін.) сім та шість видів; родина Aceraceae (Acer platanoides L., A. pseuloplatanus L., A. campestre L., й ін.) містить чотири види дерев. Інші родини (Tiliaceae, Salicaceae, Cesalpiniaceae, Fabaceae) уключають по 2-1 виду медоносних дерев. Чисельними за вмістом медоносних кущів $є$ родини Caprifoliaceae 
(Sambucus nigra L., S. racemosa L., Weigela rosea L., ін.) - п’ять видів, Cornaceae (Cornus mas L., S. sanguinea L.) - три види). Інші родини - Salicaceae (Salix caprea L.), Grossulariaceae (Grossularia reclinata (L.) Mill), Rhamnaceae (Frangula alnus Mill.), Oleaceae (Forsythia suspensa Vahl.), Viburnaceae (Viburnum opulus L.), Berberidaceae (Berberis vulgaris L.), Elaeagnaceae (Hippophae rhamnoides L.), ін. містять по 2-1 виду кущів.

Найважливіші медоноси лісництва - це Tilia cordata Mill. (нектаропродуктивність - 393 кг/га), T. platyphyllos Scop. (425 кг/га), Robinia pscudoacacia L. (164 кг/га), Rubus idaeus L. (66 кг/га), Crataegus oxyacantha L. (21 кг/га), Cerasus avium (L.) Moench. (23 кг/га), Malus sylvestris Mill. (16 кг/га), Pyrus communis L. (19 кг/га), Sorbus aucuparia L. (18 кг/га.), Rosa canina L (16 кг/га), Prunus spinosa L. (12 кг/га), Hippophae rhamnoides L. (11 кг/га) та ін. [1].

Потрібно відзначити, що в сучасних умовах лісові фітоценози лісництва до певної міри перебувають під впливом постійних рекреаційних навантажень і, згідно зі шкалою В. І. Середіна та П. Д. Марківа [8], ці насадження мають ознаки початкової дигресії й класифікується як І-ша стадія нарушеності. Довкілля підлягає відтворенню, але для цього варто, насамперед, зменшити рекреаційне навантаження на цю територію, зокрема розробити та науково обгрунтувати організацію туристичної діяльності лісництва й посилити контроль за охороною навколишнього середовища. Під час туристичного сезону в цих лісах потрібне додаткове патрулювання лісової охорони.

Крім того, для збереження медоносних рослин у фітоценозах лісництва потрібно застосувати низку лісогосподарських заходів, а саме: навколо пасік висаджувати цінні медоносні рослини, такі як липа серцелиста й широколиста, акація біла та жовта, різні види кленів і верб, малина лісова, шипшина, крушина звичайна, різні види глоду, терену тощо. Під час проведення різноманітних рубок у лісових насадженнях лісництва потрібно оберігати медоносні рослини, що зростають на лісосіках, не включати їх у рубку, залишати на ділянці (липи, верби, акацію, черешню, горобину, шипшину, калину та ін.). Здійснюючи лісовідновні роботи в лісництві, у склад лісових культур потрібно вводити черешню лісову, грушу звичайну, яблуню лісову, горобину круглолисту й чорноплідну, калину цілолисту, гледичію колючу, дерен справжній, свидину кров'яну, обліпиху крушиноподібну та ін.

Висновки й перспективи подальших досліджень. Отже, на території лісництва переважають фітоценози, у яких домінують Quercus. robur L., Fagus sylvatica L., Carpinus betulus L., Acer platanoides L, Actr pseudoplatanus L, а також Corylus avellana L, Sorbus aucuparia L., Rosa canina L., Rubus idaeus L. й ін. У цілому у фітоценозах лісництва виявлено 85 видів рослин, які входять до 53 родів та 26 родин. Із них - 46 видів (54 \%) відзначено як медоносні рослини.

Найважливіші медоноси лісництва - це Tilia cordata Mill. (нектаропродуктивність - 393 кг/га), T. platyphyllos Scop. (425 кг/га), Robinia pscudoacacia L. (164 кг/га), Rubus idaeus L. (66 кг/га), Crataegus oxyacantha L. (21 кг/га), Cerasus avium (L.) Moench. (23 кг/га), Malus sylvestris Mill. (16 кг/га), Pyrus communis L. (19 кг/га), Sorbus aucuparia L. (18 кг/га.), Rosa canina L (16 кг/га), Prunus spinosa L. (12 кг/га), Hippophae rhamnoides L. (11 кг/га) й ін.

Для покращення природної кормової бази бджільництва в лісництві потрібно вжити заходи, які збережуть медоносні рослини та сприятимуть підвищенню медозборів на пасіках. Зокрема, передусім варто стабілізувати умови природного середовища й посилити охорону лісових фітоценозів. Крім того, для збереження медоносних рослин у фітоценозах лісництва потрібно застосувати низку лісогосподарських заходів (навколо пасік висаджувати цінні медоносні рослини, оберігати медоноси, що зростають на лісосіках, у склад лісових культур уводити цінні медоносні рослини й т. ін.).

\section{Джерела та література}

1. Гайдукевич М. Е. Медоносные растения лесов Прикарпатья, их ресурсы и рациональное использование : автореф. дис. ... канд. биол. наук : спец. 03.00 .05 «Ботаника» / М. Е. Гайдукевич. - Киев, 1984. $21 \mathrm{c}$.

2. Геоботанічне районування УРСР / Г. Білик, Є. Брадіс, М. Голубець та ін. - К. : Наук. думка, 1977. - 302 с.

3. Заверуха Б. В. Флора Волыно-Подолии и ее генезис / Б. В. Заверуха. - Киев : [б. и.], 1985. - С. 50-60.

4. Определитель высших растений Украины / под ред. Ю. Н. Прокудина / Ин-т ботаники. - Киев : [б. и.],1987. $545 \mathrm{c}$.

5. Природа Івано-Франківської області / [за ред. К. І. Геренчука]. - Львів : Вища шк., 1972. - 160 с.

6. Природно-заповідні території та об’єкти Івано-Франківщини / [за ред. М. М. Приходько та В. І. Парпана]. Івано-Франківськ : Таля, 2000. - 271 с. 
7. Серебряков И. Г. Экологическая морфология растений / И. Г. Серебряков. - М. : Высш. шк., 1962. 378 с.

8. Середин В. И. Рекомендации по ведению лесного хозяйства в рекреационных лесах Карпат / В. И. Середин, П. Д. Маркив. - Ивано-Франковск : [б. и.], 1989. - 14 с.

9. Тахтаджян А. Л. Система магнолиофитов / А. Л.Тахтаджян. - Л. : [б. и.], 1987. - 439 с.

10. Типы горных лесов / под ред. Молоткова П. И. Карпатская лесоопытная станция. - Ужгород : [б. и.], 1961. - C. 15-19.

11. Швецова А. С. Методика определения количества сахаров в нектаре медоносных растений / А. С. Швецова, Е. Х. Лукьяненко. - Ленинград : [б. и.], 1972. - С. 117-121.

Гайдукевич Мария. Медоносные растения дендрофлоры Чернелицкого лесничества: анализ и охрана (Прут-Дестровское междуречье). В статье исследуются медоносные растения дендрофлоры лесных фитоценозов Чернелицкого лесничества ГП «Коломыйское ЛХ» (Прут-Днестровское междуречье). Исследованы лесные древостои и вырубки лесничества, составлен конспект дендрофлоры, выявлены медоносные древесные растения, проведен их анализ, названы наиболее ценные медоносы, указаны их нектаропродуктивность и значение.

На территории лесничества преобладают фитоценозы, в которых доминантами выступают дуб черешчатый, бук лесной, граб обыкновенный, клен остролистный, клен-явор, а также - лещина, рябина, шиповник, малина и др. В целом, в фитоценозах лесничества выявлено 85 видов древесных растений, которые относятся к 53 родам и 26 семействам, из которых 46 видов (54 \% дендрофлоры) - медоносные растения.

Медоносные растения относятся к 16 семействам и 31 роду. Наиболее численное семейство за вместимостью медоносных растений - это семейство Розовых (28\% - дендрофлоры). За жизненными формами медоносные растения дендрофлоры лесничества разделились следующим образом: деревьев - 37 \%, кустарников - 61 \% и кустиков - 2 \%. Наиболее ценными в медоносном значении являются семейства Липовых, Бобовых, Розовых и Ивовых.

В статье разработаны некоторые мероприятия по сохранению и охране медоносных растений в лесничестве.

Ключевые слова: лесные фитоценозы, дендрофлора, виды, медоносные растения, природные ресурсы, растительность.

Haydukevych Mariya. Honey Plant Dendroflora Chernelytskoho Forestry: Analysis and Protection (Prut-Dniester Interfluve). The article investigates the honey plants dendroflora forest communities Chernelitsky Forestry Enterprise «Kolomyia LH» (Prut-Dniester interfluve). Studied forest stands and forest felling, made abstract dendroflora revealed honey woody plants, their analysis, named the most valuable honey plants, nectar and contains their values.

On the territory of the forest is dominated by plant communities in which the dominant are the English oak, beech forest, hornbeam, Norway maple, maple, sycamore, and -. Hazel, rowan, rose hips, raspberries, etc. In general, the plant communities forest identified 85 species of woody plants which belong to 53 genera and 26 families of which - 46 species (54\% dendroflora) - honey plants.

Honey plants belong to 16 families and 31 species. Most of the family of the numerical capacity of honey plants $-\mathrm{a}$ family of Rosaceae ( $28 \%$ dendroflora). Over the life forms honey plants dendroflora forestry as follows: In the trees - $37 \%$, shrubs $-61 \%$ and bushes $-2 \%$. The most valuable in the value of the honey are a family of Tiliaceae, Fabaceae, Rosaceae and Salicaceae.

The paper developed some measures for the conservation and protection of honey plants in forestry.

Key words: forest plant communities, dendroflora, species, honey plants, natural resources, vegetation.

Стаття надійшла до редколегії 17.03.2016 p.

УДК 504.732 (477.82)

\author{
Олександр Кузярін, \\ Ірина Кузьмішина, \\ Лариса Коцун
}

\title{
Лучна рослинність Шацького Поозер'я
}

Уперше на підставі аналізу польових і літературних даних розроблено класифікаційну схему лучної рослинності для Шацького Поозер'я за еколого-флористичним методом Браун-Бланке. Синтаксономічний склад лучної

(C) Кузярін О., Кузьмішина І., Кочун Л., 2016 